\title{
Impact of SO2-poisoning over the lifetime of a Cu-CHA catalyst for NH3-SCR
}

Hammershøi, Peter S.; Jensen, Anker D.; Janssens, Ton V.W.

Published in:

Applied Catalysis B: Environmental

Link to article, DOI:

10.1016/j.apcatb.2018.06.039

Publication date:

2018

Document Version

Peer reviewed version

Link back to DTU Orbit

Citation (APA):

Hammershøi, P. S., Jensen, A. D., \& Janssens, T. V. W. (2018). Impact of $\mathrm{SO}_{\text {- }}$-poisoning over the lifetime of a Cu-CHA catalyst for $\mathrm{NH}_{3}$-SCR. Applied Catalysis B: Environmental, 238, 104-410.

https://doi.org/10.1016/j.apcatb.2018.06.039

\section{General rights}

Copyright and moral rights for the publications made accessible in the public portal are retained by the authors and/or other copyright owners and it is a condition of accessing publications that users recognise and abide by the legal requirements associated with these rights.

- Users may download and print one copy of any publication from the public portal for the purpose of private study or research.

- You may not further distribute the material or use it for any profit-making activity or commercial gain

- You may freely distribute the URL identifying the publication in the public portal

If you believe that this document breaches copyright please contact us providing details, and we will remove access to the work immediately and investigate your claim. 


\section{Accepted Manuscript}

Title: Impact of $\mathrm{SO}_{2}$-poisoning over the lifetime of a $\mathrm{Cu}$-CHA catalyst for $\mathrm{NH}_{3}-\mathrm{SCR}$

Authors: Peter S. Hammershøi, Anker D. Jensen, Ton V.W.

Janssens

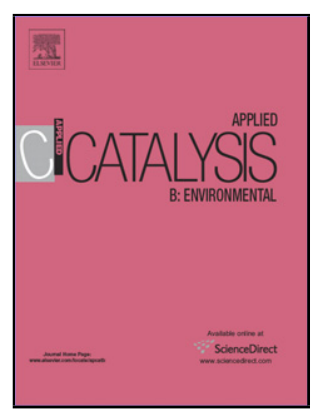

PII:

S0926-3373(18)30573-3

DOI: https://doi.org/10.1016/j.apcatb.2018.06.039

Reference: APCATB 16787

To appear in: Applied Catalysis B: Environmental

Received date: 20-4-2018

Revised date: 8-6-2018

Accepted date: $13-6-2018$

Please cite this article as: Hammershøi PS, Jensen AD, Janssens TVW, Impact of $\mathrm{SO}_{2}$ poisoning over the lifetime of a $\mathrm{Cu}-\mathrm{CHA}$ catalyst for $\mathrm{NH}_{3}-\mathrm{SCR}$, Applied Catalysis B: Environmental (2018), https://doi.org/10.1016/j.apcatb.2018.06.039

This is a PDF file of an unedited manuscript that has been accepted for publication. As a service to our customers we are providing this early version of the manuscript. The manuscript will undergo copyediting, typesetting, and review of the resulting proof before it is published in its final form. Please note that during the production process errors may be discovered which could affect the content, and all legal disclaimers that apply to the journal pertain. 
Impact of $\mathrm{SO}_{2}$-poisoning over the lifetime of a $\mathrm{Cu}-\mathrm{CHA}$ catalyst for $\mathrm{NH}_{3}-\mathrm{SCR}$

\author{
Peter S. Hammersh $\varnothing \mathrm{i}^{\mathrm{a}, \mathrm{b}}$, Anker D. Jensen ${ }^{\mathrm{b}}$, Ton V. W. Janssens ${ }^{\mathrm{a}, *}$
}

${ }^{a}$ Umicore Denmark ApS, Nøjsomhedsvej 20, 2800 Kgs. Lyngby, Denmark

${ }^{\mathrm{b}}$ Department of Chemical and Biochemical Engineering, Technical University of Denmark, Sфltofts Plads B229, 2800 Kgs. Lyngby, Denmark

"Corresponding author.Phone: +45 227546 22, e-mail address: tonv.w.janssens@eu.umicore.com

\title{
Graphical abstract
}

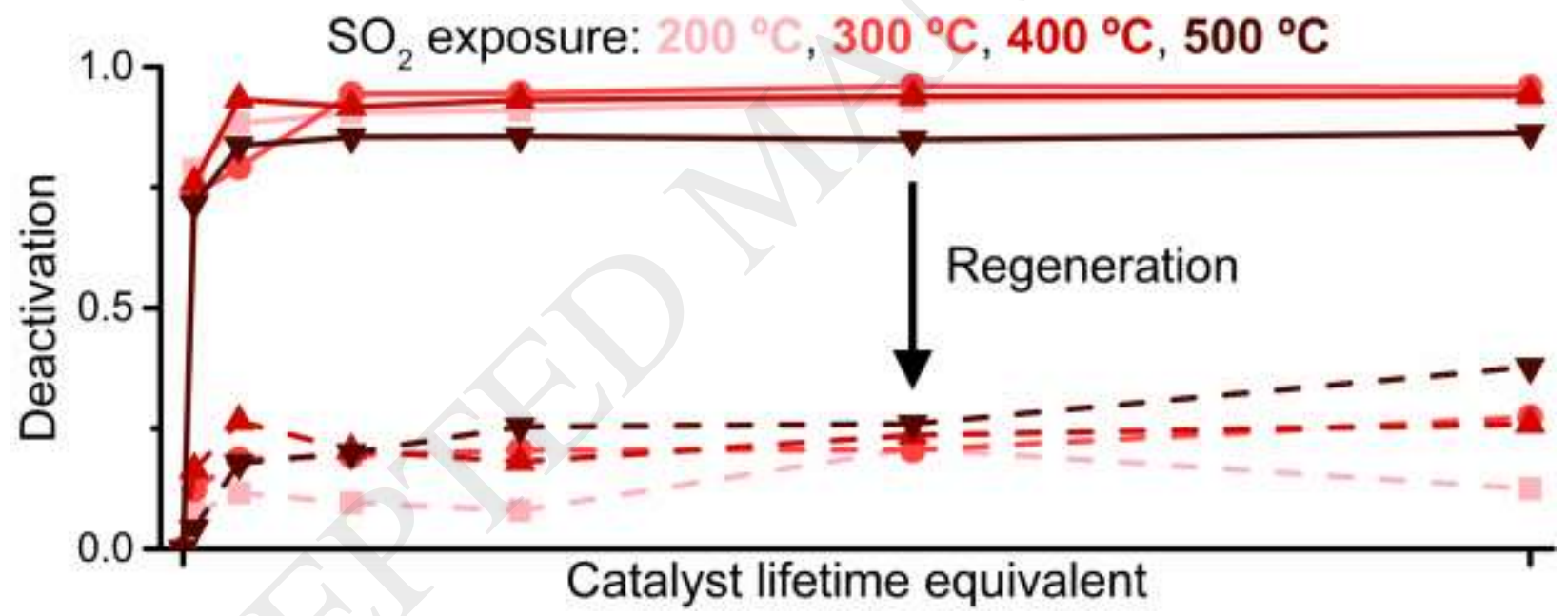

\section{Highlights}

- Deactivation of $\mathrm{Cu}-\mathrm{CHA}$ catalysts for $\mathrm{NH}_{3}-\mathrm{SCR}$ by $\mathrm{SO}_{2}$ occurs fast.

- Deactivation by $\mathrm{SO}_{2}$ can be limited to $20 \%$ by regeneration at $550{ }^{\circ} \mathrm{C}$.

- Regeneration probably feasible for handling $\mathrm{SO}_{2}$-poisoning of $\mathrm{Cu}-\mathrm{CHA} \mathrm{SCR}$ catalysts.

- $\mathrm{SO}_{2}$-poisoning appears to depend on the structural properties of $\mathrm{Cu}-\mathrm{CHA}$ materials. 


\title{
Abstract
}

$\mathrm{Cu}-\mathrm{CHA}$ catalysts for $\mathrm{NH}_{3}$-SCR in exhaust aftertreatment systems of heavy-duty vehicles, are constantly exposed to $\mathrm{SO}_{2}$ during their lifetime of about $10000 \mathrm{~h}$. In order to study the development of deactivation by $\mathrm{SO}_{2}$, a Cu-CHA catalyst was exposed to $\mathrm{SO}_{2}$ at $200,300,400$ and $500{ }^{\circ} \mathrm{C}$ for different durations up to $120 \mathrm{~h}$, resulting in total $\mathrm{SO}_{2}$ exposures that are comparable to that of the lifetime of a $\mathrm{Cu}-\mathrm{CHA}$ catalyst in an aftertreatment system. The measured deactivation increases very fast to a steady level in the range 0.85-0.95, dependent on the exposure temperature, which shows the need for frequent regeneration of the catalyst. Regeneration at $550{ }^{\circ} \mathrm{C}$ can restore the activity of the catalyst to $80 \%$ of its fresh activity level even after $120 \mathrm{~h}$ exposure, suggesting frequent regeneration as a feasible method for overcoming $\mathrm{SO}_{2}$ poisoning. ICP analyses showed that $\mathrm{SO}_{2}$ exposure led to $\mathrm{S} / \mathrm{Cu}$ ratios in the range $0.5-1$, indicating that sulfur is associated with $\mathrm{Cu}$. After regeneration the $\mathrm{S} / \mathrm{Cu}$ ratios did not exceed 0.2 , suggesting that only certain $\mathrm{Cu}$ sites are able to form $\mathrm{Cu}, \mathrm{S}$ species that are thermally stable above $550{ }^{\circ} \mathrm{C}$. This together with the observations that the deactivation before and after regeneration impact differently on the activation energy of the SCR reaction, and that the deactivation never exceeded 0.95 , suggests that $\mathrm{SO}_{2}$-poisoning of $\mathrm{Cu}-\mathrm{CHA}$ depends on the structural properties of this material. TGA measurements of the mass uptake during $\mathrm{SO}_{2}$ exposure was consistent with a process where $\mathrm{SO}_{2}$ is initially adsorbed on $\mathrm{Cu}$, and then slowly oxidized to $\mathrm{SO}_{3}$ at $200{ }^{\circ} \mathrm{C}$, whereas the mass uptake at $500{ }^{\circ} \mathrm{C}$ was consistent with an immediate adsorption of $\mathrm{SO}_{3}$, which is accredited to a faster oxidation rate at higher temperature.

\section{Keywords}

\author{
Deactivation, $\mathrm{Cu}-\mathrm{CHA}, \mathrm{SO}_{2}, \mathrm{NH}_{3}-\mathrm{SCR}$
}




\section{Introduction}

Combustion engines in vehicles produce polluting compounds, and their emissions are restricted by legislation. In particular, the emissions of $\mathrm{NO}_{\mathrm{x}}\left(\mathrm{NO}\right.$ and $\left.\mathrm{NO}_{2}\right)$ from vehicles is strictly regulated, which already has resulted in a significant improvement of air quality [1]. For diesel engines, the most effective method to reduce $\mathrm{NO}_{\mathrm{x}}$ emissions to the levels required by legislative regulations, is by selective catalytic reduction with $\mathrm{NH}_{3}\left(\mathrm{NH}_{3}-\mathrm{SCR}\right)$, and modern diesel exhaust aftertreatment systems contain one or more catalytic converters for $\mathrm{NH}_{3}-\mathrm{SCR}[2]$.

A widely used technique for dosing of $\mathrm{NH}_{3}$ in exhaust aftertreatment systems is by injection of aqueous urea, which decomposes to $\mathrm{NH}_{3}$ above $180{ }^{\circ} \mathrm{C}$ [2], setting a lower temperature limit for $\mathrm{NH}_{3}-\mathrm{SCR}$ in an exhaust system. Furthermore, the improved fuel efficiency of diesel engines that has been achieved in recent years, in order to lower the $\mathrm{CO}_{2}$ emissions, has resulted in colder exhaust gas. Consequently, it takes longer time to heat the catalysts in the exhaust aftertreatment system, and therefore, the lowtemperature activity, in particular around $180{ }^{\circ} \mathrm{C}$, has become more important for the abatement of $\mathrm{NO}_{\mathrm{x}}$ emissions.

Currently employed SCR catalysts are $\mathrm{V}_{2} \mathrm{O}_{5}$-based or zeolites containing Fe or Cu. Especially Cu-zeolites of the CHA topology are very active in the low-temperature range $180-300{ }^{\circ} \mathrm{C}$, which in combination with their high hydrothermal stability and low $\mathrm{N}_{2} \mathrm{O}$ selectivity, has made these materials particularly interesting as SCR catalysts for automotive applications [2-4]. The Al centers in the zeolite framework generates locations with negative charge, which are balanced by external cations. In the case of $\mathrm{Cu}-\mathrm{CHA}$, $\mathrm{Cu}$ in these ion-exchange positions gives rise to the activity of the $\mathrm{Cu}-\mathrm{CHA}$ catalysts for the $\mathrm{NH}_{3}-\mathrm{SCR}$ reaction. $\mathrm{Cu}-\mathrm{CHA}$ catalysts have two characteristic activity regimes, namely a low-temperature (approx. 200-300 $\left.{ }^{\circ} \mathrm{C}\right)$ and a high-temperature $\left(>350{ }^{\circ} \mathrm{C}\right)$ [5], which are separated by a region where the steady state $\mathrm{NO}_{\mathrm{x}}$ conversion actually can decrease with increasing temperature [6]. The low-temperature activity of $\mathrm{Cu}-\mathrm{CHA}$ catalysts is ascribed to the formation of mobile $\left[\mathrm{Cu}\left(\mathrm{NH}_{3}\right)_{2}\right]^{+}$complexes in the presence of NO 
and $\mathrm{NH}_{3}$, which enables formation of $\mathrm{Cu}$ pairs that efficiently dissociate $\mathrm{O}_{2}$ [7-14], which is a key step in the $\mathrm{NH}_{3}-\mathrm{SCR}$ reaction.

A drawback of Cu-zeolite catalysts is their sensitivity to $\mathrm{SO}_{2} . \mathrm{SO}_{2}$ is formed by oxidation of sulfurcontaining compounds in the fuel and engine lubrication oils. In practice, the formation of $\mathrm{SO}_{2}$ is limited by reduction of the sulfur content in diesel fuels, and therefore, the use of ultra-low sulfur diesel (ULSD) has been implemented in USA and Europe. The current maximum allowable sulfur concentration in ULSD is 15 weight ppm in USA and 10 weight ppm in Europe [1]. The use of ULSD results in a typical $\mathrm{SO}_{2}$ concentration in the exhaust gas in the range 0.5-2 volume ppm $\mathrm{SO}_{2}$. Even at such low $\mathrm{SO}_{2}$ concentrations, a considerable deactivation of $\mathrm{Cu}-\mathrm{CHA}$ catalysts, particularly in the low-temperature regime, is still observed [6,15-22].

The differences in the effect of $\mathrm{SO}_{2}$ on the performance of the different types of $\mathrm{NH}_{3}$-SCR catalysts is clearly related to the chemistry of the systems [22]. The high $\mathrm{SO}_{2}$ sensitivity for Cu-zeolites, compared to Fe-zeolites, is possibly due to the higher stability of $\mathrm{Cu}$-sulfate compared to Fe-sulfate [23]. This is consistent with the observed release of $\mathrm{SO}_{2}$ and restoration of activity of $\mathrm{Cu}-\mathrm{CHA}$ by heating to $700{ }^{\circ} \mathrm{C}$, which is above the temperature for thermal decomposition of $\mathrm{Cu}$-sulfate $[6,18,22,23]$. This suggests that the deactivation induced by $\mathrm{SO}_{2}$ is at least partially due to the formation of some $\mathrm{SO}_{3}$. In an aftertreatment system, $\mathrm{SO}_{3}$ can form from oxidation of $\mathrm{SO}_{2}$, which can take place over the diesel oxidation catalyst and also in the $\mathrm{Cu}-\mathrm{CHA}$ catalyst itself $[6,15,18,20]$. Therefore, to understand the deactivation of Cu-zeolite catalysts by $\mathrm{SO}_{2}$, the formation and interaction of $\mathrm{SO}_{3}$ with $\mathrm{Cu}$ must be considered as well. This means that the $\mathrm{SO}_{2}$-induced deactivation of $\mathrm{Cu}$-zeolites is influenced by many factors, such as temperature, gas environment, and oxidation of $\mathrm{SO}_{2}$ to $\mathrm{SO}_{3}[6,15,18,22]$, and several $\mathrm{Cu}, \mathrm{S}$ species of varying stability that can be formed [6,15-18,22,24,25].

A potentially feasible method for treating $\mathrm{SO}_{2}$-induced deactivation of $\mathrm{Cu}$-CHA catalysts in an exhaust system is by thermal regeneration of the catalyst, which is possible due to the different stabilities of the 
$\mathrm{Cu}, \mathrm{S}$ species $[6,15,18,20,22,26]$. In a typical modern aftertreatment system, an achievable maximum temperature of the SCR catalyst for regeneration is about $550{ }^{\circ} \mathrm{C}$. Regeneration of a $\mathrm{Cu}-\mathrm{CHA}$ catalyst at this temperature reverses the predominant part of the deactivation [6]. Thus, the total deactivation measured after exposure to $\mathrm{SO}_{\mathrm{x}}$ can be divided into a reversible and an irreversible part, by measuring the irreversible deactivation after regeneration at $550{ }^{\circ} \mathrm{C}[6]$.

The required lifetime of an SCR catalyst in an aftertreatment system of a heavy-duty diesel vehicle is about $10000 \mathrm{~h}$. Throughout its lifetime, the SCR catalyst is constantly exposed to low concentrations of $\mathrm{SO}_{2}$, which makes the deactivation a continuous process persisting over the lifetime of the catalyst. Therefore, it is important to know the impact of these low $\mathrm{SO}_{2}$ concentrations over long-term $\mathrm{SO}_{2}$ exposure. The deactivation process can be accelerated by increasing the $\mathrm{SO}_{2}$ concentration [22], because the deactivation appears to depend on the total $\mathrm{SO}_{2}$ exposure [22], defined as the product of the $\mathrm{SO}_{2}$ concentration and the exposure time. In this way, the development of the reversible and irreversible deactivation over the lifetime of the catalyst can be assessed from experiments of significantly shorter exposure times, but with higher $\mathrm{SO}_{2}$ concentrations.

In this contribution, the deactivation and regeneration of a $\mathrm{Cu}-\mathrm{CHA}$ catalyst is investigated for $\mathrm{SO}_{2}$ exposures of increasing duration up to $120 \mathrm{~h}$ and with $50 \mathrm{ppmv} \mathrm{SO}_{2}$, which is comparable to the total $\mathrm{SO}_{2}$ exposure of a commercial $\mathrm{Cu}-\mathrm{CHA} \mathrm{SCR}$ catalyst during its required lifetime. The deactivation is evaluated by comparing the performance of the catalysts in the $\mathrm{NH}_{3}-\mathrm{SCR}$ reaction after $\mathrm{SO}_{2}$ exposure at $200-500{ }^{\circ} \mathrm{C}$, and after regeneration at $550{ }^{\circ} \mathrm{C}$, to that of the fresh. This is important, in order to assess the impact of the reversible and irreversible deactivation development over long-term $\mathrm{SO}_{2}$ exposure.

Furthermore, the catalytic performance is compared to the $S$ uptake of the catalysts exposed at 200-500

${ }^{\circ} \mathrm{C}$, as determined by ICP, and to in situ thermogravimetric measurements of $\mathrm{SO}_{2}$ exposure at 200 and 500 ${ }^{\circ} \mathrm{C}$.

\section{Experimental}


The zeolite material used in this study is a CHA zeolite with a Si/Al ratio of 14.6. Cu was introduced in the zeolite by mixing it with the appropriate amount of an aqueous $\mathrm{Cu}\left(\mathrm{NO}_{3}\right)_{2}$ solution to obtain $2.5 \mathrm{wt} \%$ $\mathrm{Cu}$ in the zeolite. After mixing, the slurry was dried at $120^{\circ} \mathrm{C}$ and calcined at $550{ }^{\circ} \mathrm{C}$ for $3 \mathrm{~h}$. The calcined catalyst powder was light blue, indicating that $\mathrm{Cu}$ is located in the ion-exchange positions of the CHA material. The $\mathrm{Si}, \mathrm{Al}$ and $\mathrm{Cu}$ content were determined by ICP-OES to be $37.5,2.46$, and 2.43 wt $\%$, respectively, corresponding to a $\mathrm{Cu} / \mathrm{Al}$ ratio of 0.42 , and estimated $2.76 \mathrm{wt} \% \mathrm{Cu}$ on a dry matter basis.

The $\mathrm{SO}_{2}$ exposures were carried out in a flow reactor setup, equipped with 4 parallel quartz reactor tubes, each with independent control of the temperature. A sample of $1.6 \mathrm{~g}$ of fresh catalyst powder (sieve fraction 150-300 $\mu \mathrm{m}$ ) was added to each reactor tube and held in place by quartz wool plugs. Prior to $\mathrm{SO}_{2}$ exposure, all catalyst loadings were heated to $500{ }^{\circ} \mathrm{C}$ for $2 \mathrm{~h}$ in a flow of $10 \% \mathrm{O}_{2}, 5 \% \mathrm{H}_{2} \mathrm{O}$, and sufficient $\mathrm{N}_{2}$ to obtain a total flow rate of $1.67 \mathrm{NL} / \mathrm{min}$. Then, one reactor was kept at $500{ }^{\circ} \mathrm{C}$, and the other three reactors were cooled to 200,300 , and $400{ }^{\circ} \mathrm{C}$. For the $\mathrm{SO}_{2}$ exposure, $50 \mathrm{ppmv} \mathrm{SO}_{2}$ was added to the reactor feed, while keeping the same total flow rate. In 6 different runs, the duration of $\mathrm{SO}_{2}$ exposure was varied and chosen as $1,5,15,30,65,120 \mathrm{~h}$. In this way, a total of 24 catalyst samples were obtained, each with different $\mathrm{SO}_{2}$ exposure duration and temperature. Finally, $0.8 \mathrm{~g}$ of each of these 24 samples was regenerated in the same parallel reactor setup by exposing to $550{ }^{\circ} \mathrm{C}$ for $6 \mathrm{~h}$ in a flow of 10 $\% \mathrm{O}_{2}, 5 \% \mathrm{H}_{2} \mathrm{O}$, and $\mathrm{N}_{2}$ to balance the flow to $1.67 \mathrm{NL} / \mathrm{min}$.

This yields a total of 48 treated catalyst samples, 24 exposed to $\mathrm{SO}_{2}$ and 24 regenerated, which were all analyzed for $\mathrm{Cu}$ and $\mathrm{S}$ content using ICP-OES in order to determine the S/Cu ratio after each treatment of the catalyst.

The $\mathrm{NH}_{3}$-SCR activity measurements were done in a microreactor setup, by adding $5 \mathrm{mg}$ (dry matter basis) catalyst powder, 150-300 $\mu \mathrm{m}$ sieve fraction, to a quartz U-tube reactor with an inner diameter of 2 $\mathrm{mm}$, using quartz wool to keep the catalyst in place. The reactor feed gas consisted of 500 ppmv NO, 533 ppmv $\mathrm{NH}_{3}, 10 \% \mathrm{O}_{2}, 5 \% \mathrm{H}_{2} \mathrm{O}$, in $\mathrm{N}_{2}$ at a total flow rate of $225 \mathrm{NmL} / \mathrm{min}$. To measure the $\mathrm{NH}_{3}-\mathrm{SCR}$ 
activity, the catalyst was heated stepwise to $160,180,190,200,210,220,250,300,325,350,400$, and $550{ }^{\circ} \mathrm{C}$ and kept at these temperatures for $40 \mathrm{~min}$ to ensure stationary conditions. The concentrations of $\mathrm{NO}, \mathrm{NH}_{3}, \mathrm{NO}_{2}$, and $\mathrm{N}_{2} \mathrm{O}$ in the reactor exit gas were monitored continuously by a Gasmet CX4000 FTIR analyzer, connected to the reactor outlet. The feed gas concentrations were measured by bypassing the reactor, using the same FTIR analyzer.

To determine the $\mathrm{NH}_{3}$-SCR activity, the steady state conversion was determined from the activity measurement, and converted to a rate constant according to:

$$
k=-\frac{F}{W} \ln (1-X)
$$

where $F$ is the total molar flow rate, $W$ is the catalyst mass, and $X$ is the NO conversion. For the deactivation we use our earlier definition [6] in which the rate constants of the catalysts exposed to $\mathrm{SO}_{2}$ before or after regeneration $(k)$ are related to the corresponding rate constant of the fresh catalyst $\left(k_{\text {fresh }}\right)$, as expressed in:

$$
\text { Deactivation }=1-\frac{k}{k_{\text {fresh }}}
$$

Finally, the uptake of sulfur at $200{ }^{\circ} \mathrm{C}$ and $500{ }^{\circ} \mathrm{C}$ was followed by thermogravimetric analysis (TGA) in two separate measurements. For these measurements, a sample of the fresh catalyst was heated to $550{ }^{\circ} \mathrm{C}$ for $1 \mathrm{~h}$ in $10 \% \mathrm{O}_{2}$ in $\mathrm{N}_{2}$, at a total flow rate of $150 \mathrm{NmL} / \mathrm{min}$, to obtain the dry mass of the catalyst. The dry masses of the samples used were $25.9252 \mathrm{mg}$ (S uptake at $200{ }^{\circ} \mathrm{C}$ ) and $37.6135 \mathrm{mg}$ (S uptake at 500 ${ }^{\circ} \mathrm{C}$ ). Then, the catalyst was exposed to $\mathrm{SO}_{2}$ at $200{ }^{\circ} \mathrm{C}$ or $500{ }^{\circ} \mathrm{C}$, using a feed gas consisting of $50 \mathrm{ppmv}$ $\mathrm{SO}_{2}, 3 \% \mathrm{H}_{2} \mathrm{O}$ and $10 \% \mathrm{O}_{2}$ in $\mathrm{N}_{2}$, also at a total flow rate of $150 \mathrm{NmL} / \mathrm{min}$, while monitoring the change in catalyst mass. Changes in catalyst mass during regeneration were obtained by heating to $550{ }^{\circ} \mathrm{C}$ and changing the feed gas to $10 \% \mathrm{O}_{2}$ in $\mathrm{N}_{2}$, while keeping the same total flow rate. The changes in $\mathrm{S}$ uptake are determined from the weight changes in alternating $\mathrm{SO}_{2}$ exposure and regeneration phases at a fixed 
temperature $\left(200\right.$ or $\left.500{ }^{\circ} \mathrm{C}\right)$, where catalysts are regenerated after the same cumulative durations of the $\mathrm{SO}_{2}$ exposure as used in the deactivation measurements given above.

\section{Results}

Figure 1 shows the development of the steady state NO conversions as function of the temperature over the duration of exposure to $\mathrm{SO}_{2}$ at $200{ }^{\circ} \mathrm{C}$, and after subsequent regeneration by heating at $550{ }^{\circ} \mathrm{C}$ for $6 \mathrm{~h}$. In all cases, the NO conversion in the temperature range $160-350{ }^{\circ} \mathrm{C}$ is considerably lower after exposure to $\mathrm{SO}_{2}$, compared to the fresh catalyst. Regeneration at $550{ }^{\circ} \mathrm{C}$ mostly restores the $\mathrm{NO}$ conversion in that temperature range. The same trends are observed after exposure to $\mathrm{SO}_{2}$ at $300{ }^{\circ} \mathrm{C}, 400{ }^{\circ} \mathrm{C}$, and $500{ }^{\circ} \mathrm{C}$, see supporting information. This behavior can be described in terms of reversible and irreversible deactivation as defined earlier [6]. The deactivation remaining after regeneration is then the irreversible deactivation, and the reversible deactivation is defined as the difference in deactivation of the $\mathrm{SO}_{2}$ exposed catalyst before and after regeneration [6].

The total $\mathrm{SO}_{2}$ exposure, which corresponds to the product of the exposure time and $\mathrm{SO}_{2}$ concentration, appears to be a good descriptor for deactivation by $\mathrm{SO}_{2}$ [22], which also allows for estimation of the deactivation over the entire required lifetime of the catalyst. Figure 2 summarizes the development of the reversible and irreversible deactivation with $\mathrm{SO}_{2}$ exposure for the exposure temperatures of 200, 300, 400 , and $500{ }^{\circ} \mathrm{C}$, along with the corresponding S/Cu ratio measured by ICP. Both the reversible and irreversible deactivation initially show a fast increase with $\mathrm{SO}_{2}$ exposure, and reach a final level after an $\mathrm{SO}_{2}$ exposure of $500-1000 \mathrm{ppm} \cdot \mathrm{h}$, after which the deactivation remains constant. It is noted that the predominant part of the final deactivation level is reached already after $50 \mathrm{ppm} \cdot \mathrm{h}$, which is the first data point in each $\mathrm{SO}_{2}$ exposure series, indicating that the effect of $\mathrm{SO}_{2}$ is almost immediate. The final deactivation after $\mathrm{SO}_{2}$ exposure, before regeneration, is 0.85-0.95 and depends on the temperature of $\mathrm{SO}_{2}$ exposure. The irreversible deactivation is about 0.2-0.3, independent of the temperature for $\mathrm{SO}_{2}$ 
exposure. It is also noted that we have not found any conditions in which a complete deactivation of the $\mathrm{Cu}-\mathrm{CHA}$ is observed.

In order to relate the measured deactivation of the $\mathrm{Cu}$-CHA catalyst with the sulfur uptake, the deactivation is compared to the measured $\mathrm{S} / \mathrm{Cu}$ ratios before and after regeneration. The $\mathrm{S} / \mathrm{Cu}$ ratios of the regenerated states of the catalyst mirrors the observed irreversible deactivation, with a rapid increase during the first $1000 \mathrm{ppm} \cdot \mathrm{h} \mathrm{SO}$, followed by a constant final level of about 0.2 , independent of the temperature of $\mathrm{SO}_{2}$ exposure. This value matches the observed deactivation level of 0.2-0.3 quite well, suggesting that the irreversible deactivation is related to the adsorption of sulfur on the active $\mathrm{Cu}$ sites.

The measured $\mathrm{S} / \mathrm{Cu}$ ratios before regeneration do not appear to reach a final level. The $\mathrm{S} / \mathrm{Cu}$ ratios initially increase fast, which parallels the fast increase of the deactivation, but after about $1000 \mathrm{ppm} \cdot \mathrm{h}$ $\mathrm{SO}_{2}$, the $\mathrm{S} / \mathrm{Cu}$ ratio continues to increase at a lower rate, except for the catalysts exposed to $\mathrm{SO}_{2}$ at 500 ${ }^{\circ} \mathrm{C}$. The measured $\mathrm{S} / \mathrm{Cu}$ ratios are, in most cases, lower than the observed levels of deactivation, which indicates that the reversible deactivation cannot be directly explained by $\mathrm{Cu}$ site blocking with sulfur. Nevertheless, the observation that the $\mathrm{S} / \mathrm{Cu}$ ratios generally are lower than 1 indicates that the uptake of sulfur is related to the $\mathrm{Cu}$ and is consistent with adsorption of sulfur on $\mathrm{Cu}$.

A more detailed comparison of the measured $\mathrm{S} / \mathrm{Cu}$ ratios and the reversible and irreversible deactivation, is shown in Figure 3. The reversible deactivation is always disproportionately larger than the corresponding S/Cu ratios, while the irreversible deactivation generally is closer to a 1:1 correlation with the S/Cu ratio, which would be expected for deactivation by single site blocking. This shows that the impact of sulfur uptake on the reversible deactivation is larger compared to the irreversible deactivation. This also suggests that the reversible and irreversible deactivation are related to the formation of different $\mathrm{Cu}, \mathrm{S}$ species or selective adsorption of sulfur on specific $\mathrm{Cu}$-sites.

The difference between reversible and irreversible deactivation is also reflected in the apparent activation energy for the $\mathrm{NH}_{3}-\mathrm{SCR}$ reaction. Figure 4 shows the apparent activation energies for the different $\mathrm{SO}_{2}$ 
exposures before and after regeneration. Clearly, for the catalysts before regeneration, the activation energy is lowered from about $70 \mathrm{~kJ} / \mathrm{mol}$ to about $30 \mathrm{~kJ} / \mathrm{mol}$ for an $\mathrm{SO}_{2}$ exposure of about $1000 \mathrm{ppm} \cdot \mathrm{h}$, which coincides with the observed fast increase in deactivation and initial uptake of sulfur. At longer $\mathrm{SO}_{2}$ exposures, the apparent activation energy remains constant. For the regenerated catalysts, all measured activation energies are about $70 \mathrm{~kJ} / \mathrm{mol}$, which is close to the value of the fresh catalyst, independent of $\mathrm{SO}_{2}$ exposure time or temperature. This means that the level of deactivation of the $\mathrm{Cu}-\mathrm{CHA}$ catalyst by $\mathrm{SO}_{2}$ is not only the result of a certain amount of $\mathrm{S}$ in the catalyst, but also depends on which $\mathrm{Cu}, \mathrm{S}$ species that are present. The different trends observed for the activation energies before and after regeneration are also an indication of different mechanisms for the SCR reaction on the reversibly and irreversibly deactivated $\mathrm{Cu}-\mathrm{CHA}$ catalysts, in agreement with an earlier conclusion [6].

The different influence of the $\mathrm{SO}_{2}$ exposure temperature on the sulfur uptake related to the reversible or irreversible deactivation is illustrated in Figure 5, which shows the measured $\mathrm{S} / \mathrm{Cu}$ ratios as function of the exposure temperatures. As also noted above, the $\mathrm{S} / \mathrm{Cu}$ ratios related to the irreversible deactivation reach approximately 0.2 for all exposure temperatures, which suggests that the irreversible deactivation is related to the formation of a $\mathrm{Cu}, \mathrm{S}$ species at certain $\mathrm{Cu}$ sites. The $\mathrm{S} / \mathrm{Cu}$ ratios related to the reversible deactivation in Figure 5 show a maximum sulfur uptake at $400{ }^{\circ} \mathrm{C}$ for short $\mathrm{SO}_{2}$ exposure $(1$ and $5 \mathrm{~h})$, and at $300{ }^{\circ} \mathrm{C}$ for the longer $\mathrm{SO}_{2}$ exposures. This trend is similar to that observed on a $\mathrm{Cu}-\mathrm{SAPO}-34$ catalyst exposed to $\mathrm{SO}_{2}$ in $\mathrm{O}_{2}$ and $\mathrm{H}_{2} \mathrm{O}$ at different temperatures [22], and reflects a trade-off between the kinetics of the formation of the $\mathrm{Cu}$ sulfate species and the equilibrium adsorption concentration [22].

TGA measurements were used to assess the sulfur uptake during $\mathrm{SO}_{2}$ exposure at $200{ }^{\circ} \mathrm{C}$ and $500{ }^{\circ} \mathrm{C}$ in more detail, to better understand the effect of $\mathrm{SO}_{2}$ at low and high temperature. Figure 6 shows how the relative mass of the catalyst (with the dry mass of the catalyst before $\mathrm{SO}_{2}$ exposure as basis) changes with the total $\mathrm{SO}_{2}$ exposure. Both at $200{ }^{\circ} \mathrm{C}$ and $500{ }^{\circ} \mathrm{C}, \mathrm{SO}_{2}$ exposure leads to a steep increase in the catalyst 
mass at $\mathrm{SO}_{2}$ exposures below $500 \mathrm{ppm} \cdot \mathrm{h}$. At $500{ }^{\circ} \mathrm{C}$, a relative mass of 1.02 is reached, which remains stable after longer exposures to $\mathrm{SO}_{2}$, while at $200{ }^{\circ} \mathrm{C}$, the relative mass initially increases to 1.01 , which then increases further to approximately $1.03 \mathrm{after} 6000 \mathrm{ppm} \cdot \mathrm{h} \mathrm{SO} \mathrm{S}_{2}$ exposure. This is qualitatively the same trend as found for the $\mathrm{S} / \mathrm{Cu}$ ratio (Figure 2), which is an indication that the observed increase in catalyst mass is indeed due to the uptake of $\mathrm{SO}_{2}$.

For a more precise interpretation of the observed increase in catalyst mass upon exposure to $\mathrm{SO}_{2}$ at 200 ${ }^{\circ} \mathrm{C}$ and $500{ }^{\circ} \mathrm{C}$, we need to know in which form the $\mathrm{SO}_{2}$ is adsorbed on the catalyst. The most obvious options are adsorption of $\mathrm{SO}_{2}$ or $\mathrm{SO}_{3}$, and the formation of sulfites and sulfates on the $\mathrm{Cu}$ sites $[6,15,16,18,22]$. By comparing the observed increases in catalyst mass measured in the TGA experiments with the measured $\mathrm{S} / \mathrm{Cu}$ ratios given in Figures 2 and 5, it is possible to work out whether the sulfur is adsorbed as $\mathrm{SO}_{2}$ or $\mathrm{SO}_{3}$. First, the observed increase in catalyst mass is converted to a molar amount of sulfur, under the assumption that the sulfur is present as either $\mathrm{SO}_{2}$ or $\mathrm{SO}_{3}$, which together with the known $\mathrm{Cu}$ content, $2.76 \mathrm{wt} \%$ on dry matter basis, results in an estimated $\mathrm{SO}_{2} / \mathrm{Cu}$ and $\mathrm{SO}_{3} / \mathrm{Cu}$ ratio. In Figure 7, these estimated $\mathrm{SO}_{2} / \mathrm{Cu}$ and $\mathrm{SO}_{3} / \mathrm{Cu}$ ratios are compared to the measured $\mathrm{S} / \mathrm{Cu}$ ratios determined by ICP, for $\mathrm{Cu}-\mathrm{CHA}$ exposed to $\mathrm{SO}_{2}$ at $200{ }^{\circ} \mathrm{C}$ and $500{ }^{\circ} \mathrm{C}$. At an $\mathrm{SO}_{2}$ exposure temperature of $200{ }^{\circ} \mathrm{C}$, the $\mathrm{SO}_{2} / \mathrm{Cu}$ ratios follow the measured $\mathrm{S} / \mathrm{Cu}$ ratios to $1000 \mathrm{ppm} \cdot \mathrm{h}$ of $\mathrm{SO}_{2}$ exposure. At $6000 \mathrm{ppm} \cdot \mathrm{h} \mathrm{SO}$, the measured $\mathrm{S} / \mathrm{Cu}$ ratio matches the estimated $\mathrm{SO}_{3} / \mathrm{Cu}$ ratio. This indicates that initially it is $\mathrm{SO}_{2}$ that is adsorbed on the $\mathrm{Cu}$, but it is slowly oxidized to $\mathrm{SO}_{3}$. With an $\mathrm{SO}_{2}$ exposure temperature of $500{ }^{\circ} \mathrm{C}$, the estimated $\mathrm{SO}_{3} / \mathrm{Cu}$ ratio matches the $\mathrm{S} / \mathrm{Cu}$ ratio over the entire $\mathrm{SO}_{2}$ exposure duration. This clearly shows that at $500{ }^{\circ} \mathrm{C}$, oxidation of $\mathrm{SO}_{2}$ is faster, and adsorption is essentially as $\mathrm{SO}_{3}$. Adsorption of $\mathrm{SO}_{3}$ on a $\mathrm{Cu}$ $\mathrm{OH}$ species actually corresponds to the formation of a bisulfate species, which have been proposed earlier as being the cause of the irreversible deactivation $[6,15,16,18-22,24,25]$.

\section{Discussion}


The results presented above clearly show that $\mathrm{SO}_{2}$ primarily affects the low-temperature activity of $\mathrm{Cu}$ CHA catalysts for SCR, and therefore, the impacts of $\mathrm{SO}_{2}$ on the high-temperature activity will not be discussed further here.

For an SCR catalyst that has a required lifetime of about $10000 \mathrm{~h}$, it is important to be able to estimate the performance for the entire lifetime. One way to do this is by comparison of the total $\mathrm{SO}_{2} / \mathrm{Cu}$ exposure for the lifetime of the catalyst in a heavy-duty vehicle to similar conditions in a test. The total $\mathrm{SO}_{2} / \mathrm{Cu}$ exposure for a $\mathrm{Cu}-\mathrm{CHA}$ catalyst over its lifetime is about 44 , assuming that the vehicle covers $800000 \mathrm{~km}$ with a consumption of $30 \mathrm{~L} / 100 \mathrm{~km}$, using $5 \mathrm{wt}$ ppm S diesel, and with a Cu-loading of $45 \mathrm{~g}$ of the $\mathrm{Cu}$ CHA SCR catalyst. The total molar $\mathrm{SO}_{2} / \mathrm{Cu}$ exposure in the experiments presented in this article is 41.7 after $120 \mathrm{~h}$, which is similar to the typical $\mathrm{SO}_{2} / \mathrm{Cu}$ exposure in an exhaust system. Therefore, we expect that the development of $\mathrm{SO}_{2}$-poisoning in our experiments reflect that of a $\mathrm{Cu}-\mathrm{CHA} \mathrm{SCR}$ catalyst in an exhaust aftertreatment system.

The results presented in this study shows that the reversible deactivation increases fast to a high level, independent of the $\mathrm{SO}_{2}$ exposure temperature. This means that the SCR catalyst in an exhaust system requires frequent regeneration in order to maintain an efficient $\mathrm{NH}_{3}$-SCR performance, especially in the context of cold start where the low-temperature activity is particularly important. Based on the presented results, it is actually possible to restore the predominant part of the original activity of the catalyst throughout its lifetime, by regeneration at $550{ }^{\circ} \mathrm{C}$. This shows that $\mathrm{SO}_{2}$-poisoning of $\mathrm{Cu}$-CHA catalysts is occurring over the lifetime of the catalyst, but that it can be managed by proper regeneration strategies. Furthermore, the irreversible deactivation seems sufficiently small to be handled by appropriate system design.

The use of $\mathrm{Cu}-\mathrm{CHA}$ catalysts in exhaust systems appears to rely on the efficiency of regeneration, which likely depends on the $\mathrm{SO}_{2}$ concentration during regeneration. Thus, exposure to $50 \mathrm{ppmv} \mathrm{SO}_{2}$ at $500{ }^{\circ} \mathrm{C}$ leads to uptake of sulfur by the catalyst, while regeneration at $550{ }^{\circ} \mathrm{C}$ in the absence of $\mathrm{SO}_{2}$ partially 
removes sulfur from the catalyst. Furthermore, reversible and irreversible deactivation of a Cu-SAPO-34 catalyst have been shown to build up when exposed to $\mathrm{SO}_{2}$ concentrations as low as $1.5 \mathrm{ppmv}$ at $500{ }^{\circ} \mathrm{C}$ [22]. Therefore, it appears that the uptake or removal of sulfur depends on the $\mathrm{SO}_{2}$ concentration being above or below a critical value, which is somewhere in the range $0-1.5 \mathrm{ppmv} \mathrm{SO}_{2}$. This could potentially complicate the regeneration if the $\mathrm{SO}_{2}$ content of the exhaust gas is above the critical concentration, in which case a regeneration would resemble the $\mathrm{SO}_{2}$ exposure at $500{ }^{\circ} \mathrm{C}$. In that case, the low-temperature activity of $\mathrm{Cu}-\mathrm{CHA}$ catalysts would be lost relatively fast, and so would the main advantage of using these materials compared to Fe-zeolites or vanadia-based systems. The efficiency of regeneration, and the critical $\mathrm{SO}_{2}$ concentration, would have to be verified in an actual exhaust system, since reducing compounds in the exhaust gas, such as hydrocarbons and $\mathrm{NH}_{3}$, have been shown to have a beneficial effect for removing sulfurous compounds from $\mathrm{Cu}-\mathrm{CHA}$ catalysts [26].

The process for the uptake of sulfur by the $\mathrm{Cu}-\mathrm{CHA}$ catalyst possibly proceeds by an initial adsorption of $\mathrm{SO}_{2}$ on $\mathrm{Cu}$ where the sulfur is subsequently oxidized to sulfate. This is envisioned because the $\mathrm{Cu}-\mathrm{CHA}$ catalyst is exposed to $\mathrm{SO}_{2}$, which must oxidize in order to constitute the forms of sulfate that are associated with the $\mathrm{Cu}, \mathrm{S}$ species causing the reversible $[6,15,16,18,22]$ and irreversible deactivation $[6,22]$. The proposed process is consistent with the results from the TGA experiment at $200{ }^{\circ} \mathrm{C}$ (Figure 7), where the initial mass uptake fits with an uptake of $\mathrm{SO}_{2}$, and over time changes to fit better with an uptake of $\mathrm{SO}_{3}$. At this temperature $\left(200{ }^{\circ} \mathrm{C}\right)$, there is a clear difference between the initial and final uptake, which indicates that the oxidation of $\mathrm{SO}_{2}$ is kinetically controlled. In the TGA experiment at 500 ${ }^{\circ} \mathrm{C}$, the mass uptake fits with a constant uptake of $\mathrm{SO}_{3}$, which can be explained by a faster oxidation of $\mathrm{SO}_{2}$ at this temperature $[20,22]$, which both could be on the $\mathrm{Cu}$ sites or in the gas phase.

A possible reason for the disproportionally high reversible deactivation, as compared to the $\mathrm{S} / \mathrm{Cu}$ ratio, is that the adsorption of $\mathrm{SO}_{2}$ affects the mobility and effective amount of $\left[\mathrm{Cu}\left(\mathrm{NH}_{3}\right)_{2}\right]^{+}$ions in the $\mathrm{Cu}-\mathrm{CHA}$ zeolite. The current understanding of the low-temperature part of the SCR mechanism is that the mobile $\left[\mathrm{Cu}\left(\mathrm{NH}_{3}\right)_{2}\right]^{+}$complexes allow for the formation of pairs of $\mathrm{Cu}$ ions, which are crucial for the dissociation 
of the oxygen molecules $[8,11]$. As a consequence, the activity depends on the square of the $\mathrm{Cu}$ density below a certain $\mathrm{Cu}$ loading, and depends linearly on the $\mathrm{Cu}$ density above it [8]. This results in two distinct activity regimes, which may be related to the different impacts of the sulfur loading on the reversible and irreversible deactivation. In principle, the mechanism based on mobile $\left[\mathrm{Cu}\left(\mathrm{NH}_{3}\right)_{2}\right]^{+}$ complexes implies that all $\mathrm{Cu}$ sites are the same, namely the mobile $\left[\mathrm{Cu}\left(\mathrm{NH}_{3}\right)_{2}\right]^{+}$complex, and contribute equally to the activity. Ultimately, the activity is determined by the amount of $\mathrm{Cu}$ pairs that are formed at the given conditions. The different trends for the activation energy of the SCR reaction with reversible and irreversible deactivation, as shown in Figure 4, and the disproportionately larger reversible deactivation than irreversible deactivation as compared to the $\mathrm{S} / \mathrm{Cu}$ ratios shown in Figure 3 can be understood in relation to the two activity regimes. Since the $\mathrm{S} / \mathrm{Cu}$ ratios related to the irreversible deactivation are always lower than those related to the reversible deactivation, and lower than 0.2 , the amount of deactivated $\mathrm{Cu}$ in these cases may be sufficiently small to keep the amount of non-deactivated $\mathrm{Cu}$ in the linear dependence regime. The activity is then not limited by formation of $\mathrm{Cu}$ pairs, and the deactivation would simply correspond to a loss of active sites, which is also consistent with the values of the activation energies close to that of the fresh catalyst. For the reversible deactivation, the S/Cu ratios of 0.3-1 could enforce a situation where the effective $\mathrm{Cu}$ content becomes sufficiently low for the activity to be restricted by formation of $\mathrm{Cu}$ pairs. In this situation, the activity depends on the square of the effective $\mathrm{Cu}$ density, and therefore, it would be expected that the deactivation is disproportionately larger than the $\mathrm{S} / \mathrm{Cu}$ ratio, as observed in Figure 3. The lower activation energy is then related to the fact that the rate of the SCR reaction is determined by the limited rate of $\mathrm{Cu}$ pair formation.

The observation that similar sulfur contents can result in significantly different levels of reversible and irreversible deactivation [6] is not consistent with the idea that all $\mathrm{Cu}$ sites contribute equally to the rate of the $\mathrm{NH}_{3}$-SCR reaction. Factors like the zeolite structure and $\mathrm{Al}$ distribution can also influence the reactivity or mobility of $\mathrm{Cu}$, eventually resulting in $\mathrm{Cu}$ sites of different activity. This idea is supported by two observations of the $\mathrm{SO}_{2}$ exposed and regenerated $\mathrm{Cu}-\mathrm{CHA}$ catalyst in Figure 2. The first observation 
is that the reversible deactivation never exceeds 0.95 , indicating that some $\mathrm{Cu}$ does not adsorb $\mathrm{SO}_{2}$ or is not affected by $\mathrm{SO}_{2}$, and the second observation is that the $\mathrm{S} / \mathrm{Cu}$ ratio related to the irreversible deactivation is limited to 0.2 , suggesting that the more stable $\mathrm{Cu}$ sulfate species can only form at certain $\mathrm{Cu}$ sites. According to this view, the deactivation and regeneration behavior of $\mathrm{Cu}$-CHA catalysts also depend on the structural properties of the catalyst.

\section{Conclusion}

A Cu-CHA catalyst for $\mathrm{NH}_{3}-\mathrm{SCR}$ has been exposed to $\mathrm{SO}_{2}$ at different temperatures in the range 200-500 ${ }^{\circ} \mathrm{C}$, and at durations up to $120 \mathrm{~h}$, resulting in a total $\mathrm{SO}_{2}$ exposure that is similar to what an SCR catalyst experiences over the entire lifetime in an exhaust aftertreatment system on a heavy-duty vehicle. Activity measurements after $\mathrm{SO}_{2}$ exposure, and after regeneration at $550{ }^{\circ} \mathrm{C}$, enabled measurement of the extent of deactivation of the catalyst in these two states. The deactivation of the low-temperature activity of the $\mathrm{Cu}$ CHA catalyst in the presence of $\mathrm{SO}_{2}$ occurs fast in the entire temperature window $200-500{ }^{\circ} \mathrm{C}$ to a final deactivation level in the range $0.85-0.95$, dependent on the exposure temperature. Heating in $\mathrm{SO}_{2}$-free gas to $550{ }^{\circ} \mathrm{C}$ restores the activity to about $80 \%$ of its original level, even after a total $\mathrm{S} / \mathrm{Cu}$ exposure similar to that of the lifetime of a Cu-CHA SCR catalyst in a heavy-duty diesel after treatment system. This suggests regeneration as a feasible method for handling $\mathrm{SO}_{2}$-poisoning, since proper dimensioning of the catalyst easily can treat the irreversible deactivation of maximum 0.2-0.3 that develops over long-term $\mathrm{SO}_{2}$ exposure.

Analogous to the deactivation, the $\mathrm{S} / \mathrm{Cu}$ ratios also increase fast initially, and the $\mathrm{S} / \mathrm{Cu}$ ratios of the $\mathrm{SO}_{2}$ exposed catalysts reach different levels in the range of $0.5-1$, dependent on the exposure temperature. The regenerated $\mathrm{S} / \mathrm{Cu}$ ratios never exceed 0.2 , indicating that the irreversible $\mathrm{Cu}, \mathrm{S}$ species are restricted to certain $\mathrm{Cu}$ sites. The mechanism of the sulfur uptake appears to proceed by an initial uptake of $\mathrm{SO}_{2}$ by the catalyst, followed by oxidation to sulfate on the catalyst, at a rate that increases with temperature. 
The reversible and irreversible deactivation have a different impact on the low-temperature SCR mechanism, which is seen by i) a disproportionately larger reversible deactivation relative to the $\mathrm{S} / \mathrm{Cu}$ ratio as compared with the irreversible deactivation, and ii) by the reversible deactivation causing a change in the activation energy of the SCR reaction, whereas the irreversible deactivation does not. This, together with the observations of a maximum irreversible $\mathrm{S} / \mathrm{Cu}$ ratio of 0.2 , and a maximum deactivation level of 0.95 , points to a dependence of the $\mathrm{SO}_{2}$-poisoning of $\mathrm{Cu}$-CHA catalysts on structural properties of the $\mathrm{Cu}-\mathrm{CHA}$ material.

Declarations of interest: none.

\section{Acknowledgements}

A great part of the practical work with the $\mathrm{SO}_{2}$ exposures and regenerations was conducted by research specialist Jesper Sargent Larsen (Umicore Denmark ApS) for which he is most thankfully acknowledged.

Financial support from Innovation Fund Denmark (grant number 5139-0023B) is gratefully acknowledged by PSH. 


\section{References}

[1] J.D. Miller, C. Façanha, The state of clean transport policy - A 2014 synthesis of vehicle and fuel policy developments, ICCT Rep. (2014) 73.

http://www.theicct.org/sites/default/files/publications/ICCT_StateOfCleanTransportPolicy_2014.p df.

[2] I. Nova, E. Tronconi, Urea-SCR Technology for deNOx After Treatment of Diesel Exhausts, 1st ed., Springer-Verlag, New York, 2014.

[3] F. Gao, C.H.F. Peden, J.H. Kwak, J. Szanyi, Current Understanding of Cu-Exchanged Chabazite Molecular Sieves for Use as Commercial Diesel Engine DeNO x Catalysts, Top. Catal. 56 (2013) 1441-1459. doi:10.1007/s11244-013-0145-8.

[4] A.M. Beale, F. Gao, I. Lezcano-Gonzalez, C.H.F. Peden, J. Szanyi, Recent advances in automotive catalysis for NOx emission control by small-pore microporous materials, Chem. Soc. Rev. (2015). doi:10.1039/C5CS00108K.

[5] F. Gao, E.D. Walter, M. Kollar, Y. Wang, J. Szanyi, C.H.F. Peden, Understanding ammonia selective catalytic reduction kinetics over $\mathrm{Cu} / \mathrm{SSZ}-13$ from motion of the $\mathrm{Cu}$ ions, J. Catal. 319 (2014) 1-14. doi:10.1016/j.jcat.2014.08.010.

[6] P.S. Hammershøi, Y. Jangjou, W.S. Epling, A.D. Jensen, T.V.W. Janssens, Reversible and irreversible deactivation of Cu-CHA NH3-SCR catalysts by SO2 and SO3, Appl. Catal. B. 226 (2018) 38-45. doi:10.1016/j.apcatb.2017.12.018.

[7] S. Shwan, M. Skoglundh, L.F. Lundegaard, R.R. Tiruvalam, T.V.W. Janssens, A. Carlsson, P.N.R. Vennestrøm, Solid-State Ion-Exchange of Copper into Zeolites Facilitated by Ammonia at Low Temperature, ACS Catal. 5 (2015) 16-19. doi:10.1021/cs5015139.

[8] C. Paolucci, I. Khurana, A.A. Parekh, S. Li, A.J. Shih, H. Li, J.R. Di Iorio, J.D. AlbarracinCaballero, A. Yezerets, J.T. Miller, W.N. Delgass, F.H. Ribeiro, W.F. Schneider, R. Gounder, Dynamic multinuclear sites formed by mobilized copper ions in NO x selective catalytic reduction, Science (80-. ). 357 (2017) 898-903. doi:10.1126/science.aan5630.

[9] L. Chen, J. Jansson, M. Skoglundh, H. Grönbeck, Mechanism for Solid-State Ion Exchange of Cu+ into Zeolites, J. Phys. Chem. C. 120 (2016) 29182-29189. doi:10.1021/acs.jpcc.6b09553.

[10] C. Paolucci, A.A. Parekh, I. Khurana, J.R. Di Iorio, H. Li, J.D.A. Caballero, A.J. Shih, T. Anggara, W.N. Delgass, J.T. Miller, F.H. Ribeiro, R. Gounder, W.F. Schneider, Catalysis in a Cage: Condition-Dependent Speciation and Dynamics of Exchanged Cu Cations in SSZ-13 Zeolites, J. Am. Chem. Soc. 138 (2016) 6028-6048. doi:10.1021/jacs.6b02651.

[11] F. Gao, D. Mei, Y. Wang, J. Szanyi, C.H.F. Peden, Selective Catalytic Reduction over Cu/SSZ-13: Linking Homo- and Heterogeneous Catalysis, J. Am. Chem. Soc. 139 (2017) 4935-4942. doi:10.1021/jacs.7b01128.

[12] T.V.W. Janssens, H. Falsig, L.F. Lundegaard, P.N.R. Vennestrøm, S.B. Rasmussen, P.G. Moses, F. Giordanino, E. Borfecchia, K.A. Lomachenko, C. Lamberti, S. Bordiga, A. Godiksen, S. Mossin, P. Beato, A Consistent Reaction Scheme for the Selective Catalytic Reduction of Nitrogen Oxides with Ammonia, ACS Catal. 5 (2015) 2832-2845. doi:10.1021/cs501673g. 
[13] A. Marberger, A.W. Petrov, P. Steiger, M. Elsener, O. Kröcher, M. Nachtegaal, D. Ferri, Timeresolved copper speciation during selective catalytic reduction of NO on Cu-SSZ-13, Nat. Catal. 1 (2018) 221-227. doi:10.1038/s41929-018-0032-6.

[14] F. Giordanino, E. Borfecchia, K.A. Lomachenko, A. Lazzarini, G. Agostini, E. Gallo, A. V Soldatov, P. Beato, S. Bordiga, C. Lamberti, Interaction of NH3 with Cu-SSZ-13 Catalyst: A Complementary FTIR, XANES, and XES Study, J. Phys. Chem. Lett. 5 (2014) 1552-1559.

[15] A. Kumar, M.A. Smith, K. Kamasamudram, N.W. Currier, H. An, A. Yezerets, Impact of different forms of feed sulfur on small-pore Cu-zeolite SCR catalyst, Catal. Today. 231 (2014) 75-82.

[16] Y. Jangjou, D. Wang, A. Kumar, J. Li, W.S. Epling, SO2 Poisoning of the NH3-SCR Reaction over Cu-SAPO-34: Effect of Ammonium Sulfate versus Other S-Containing Species, ACS Catal. 6 (2016) 6612-6622. doi:10.1021/acscatal.6b01656.

[17] J. Luo, D. Wang, A. Kumar, J. Li, K. Kamasamudram, N. Currier, A. Yezerets, Identification of two types of $\mathrm{Cu}$ sites in $\mathrm{Cu} / \mathrm{SSZ}-13$ and their unique responses to hydrothermal aging and sulfur poisoning, Catal. Today. 267 (2016) 3-9. doi:10.1016/j.cattod.2015.12.002.

[18] Y. Cheng, C. Lambert, D.H. Kim, J.H. Kwak, S.J. Cho, C.H.F. Peden, The different impacts of SO2 and SO3 on Cu/zeolite SCR catalysts, Catal. Today. 151 (2010) 266-270.

[19] Y. Cheng, C. Montreuil, G. Cavataio, C. Lambert, Sulfur Tolerance and DeSOx Studies on Diesel SCR Catalysts, SAE Int. J. Fuels Lubr. 1 (2008) 471-476.

[20] L. Zhang, D. Wang, Y. Liu, K. Kamasamudram, J. Li, W. Epling, SO2 poisoning impact on the NH3-SCR reaction over a commercial Cu-SAPO-34 SCR catalyst, Appl. Catal. B. 156-157 (2014) 371-377. doi:10.1016/j.apcatb.2014.03.030.

[21] W. Su, Z. Li, Y. Zhang, C. Meng, J. Li, Identification of sulfate species and their influence on SCR performance of Cu/CHA catalyst, Catal. Sci. Technol. 7 (2017) 1523-1528. doi:10.1039/C7CY00302A.

[22] P.S. Hammershøi, P.N.R. Vennestrøm, H. Falsig, A.D. Jensen, T.V.W. Janssens, Importance of the $\mathrm{Cu}$ oxidation state for the SO2-poisoning of a Cu-SAPO-34 catalyst in the NH3-SCR reaction, Appl. Catal. B. 236 (2018) 377-383. doi : 10.1016/j.apcatb.2018.05.038

[23] J. Mu, D.D. Perlmutter, Thermal Decomposition of Inorganic Sulfates and Their Hydrates, Ind. Eng. Chem. Process Des. Dev. 20 (1981) 640-646. doi:10.1021/i200015a010.

[24] K. Wijayanti, K. Xie, A. Kumar, K. Kamasamudram, L. Olsson, Effect of gas compositions on SO2 poisoning over Cu/SSZ-13 used for NH3-SCR, Appl. Catal. B. 219 (2017) 142-154. doi:10.1016/j.apcatb.2017.07.017.

[25] K.C. Hass, W.F. Schneider, Density functional studies of adsorbates in Cu-exchanged zeolites: model comparisons and SOx binding, Phys. Chem. Chem. Phys. 1 (1999) 639-648.

[26] A. Kumar, M.A. Smith, K. Kamasamudram, N.W. Currier, A. Yezerets, Chemical deSOx: An effective way to recover Cu-zeolite SCR catalysts from sulfur poisoning, Catal. Today. 267 (2016) 10-16. doi:10.1016/j.cattod.2016.01.033. 


\section{Figures captions}
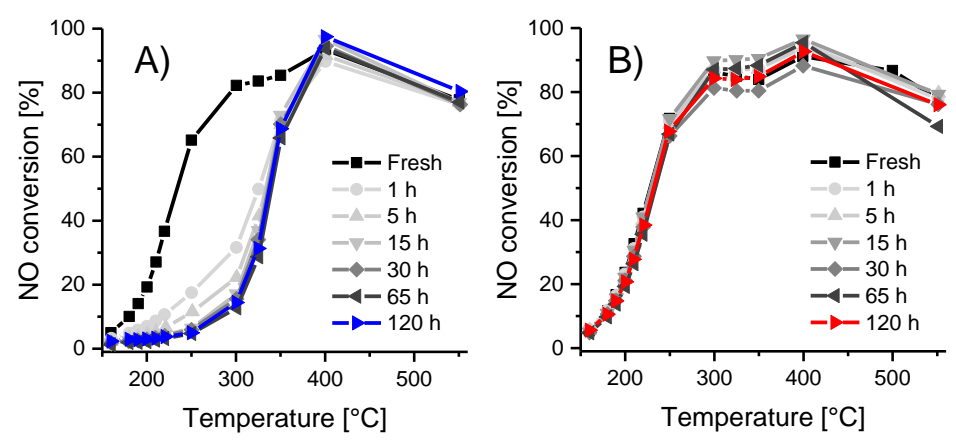

Figure 1 - Steady state $\mathrm{NO}$ conversions plotted as function of the temperature in the $\mathrm{NH}_{3}-\mathrm{SCR}$ reaction over $\left.\mathrm{A}\right)$ the $\mathrm{SO}_{2}$ exposed catalysts, and B) the regenerated catalysts. The measurements were carried out with inlet concentrations of 500 ppmv NO, 533 ppmv $\mathrm{NH}_{3}, 10 \% \mathrm{O}_{2}, 5 \% \mathrm{H}_{2} \mathrm{O}$ and $\mathrm{N}_{2}$ to a total flow rate of $225 \mathrm{NmL} / \mathrm{min}$.

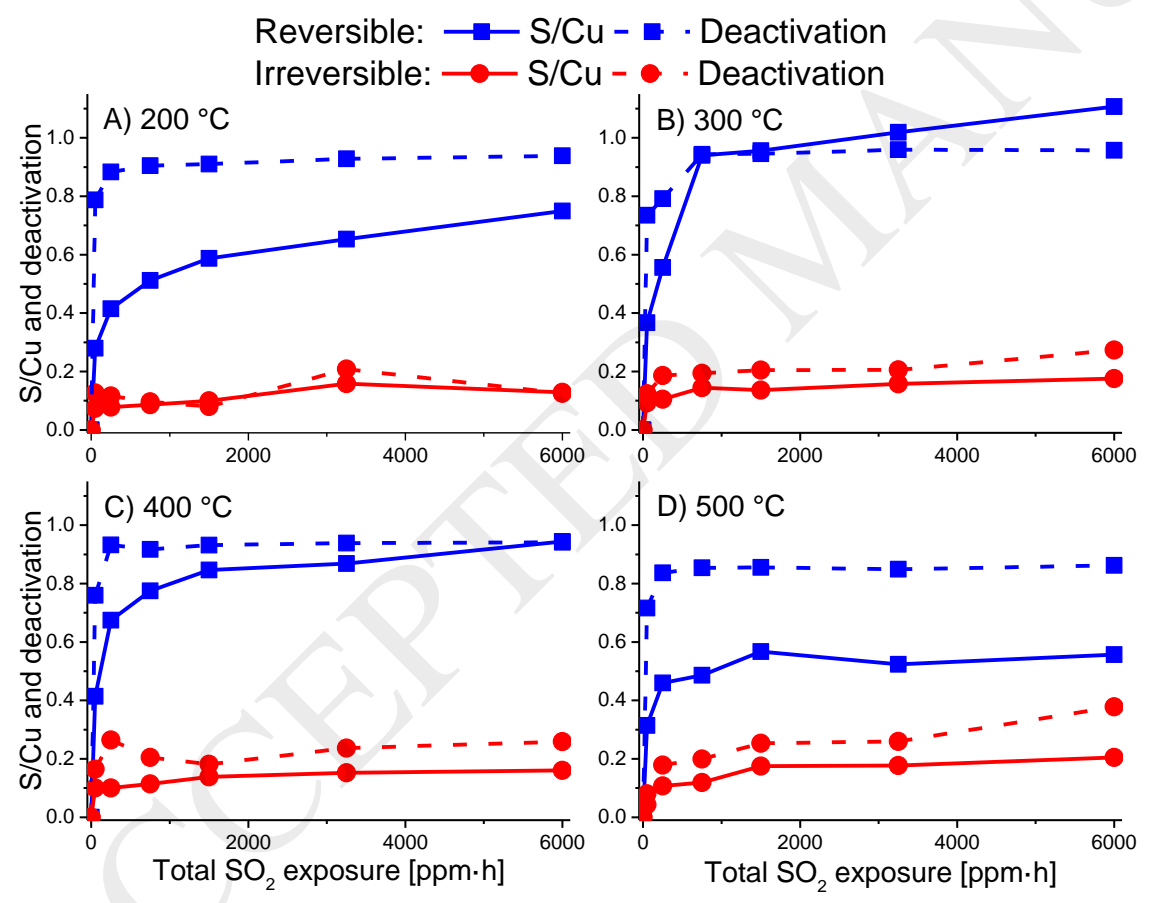

Figure 2 -Reversible (blue) and irreversible (red) deactivation at $220^{\circ} \mathrm{C}$ (dashed lines), and S/Cu ratios (solid lines), plotted as fucntions of the total $\mathrm{SO}_{2}$ exposure, for the catalysts exposed to $\mathrm{SO}_{2}$ at $\left.\left.\left.\mathrm{A}\right) 200{ }^{\circ} \mathrm{C}, \mathrm{B}\right) 300{ }^{\circ} \mathrm{C}, \mathrm{C}\right) 400{ }^{\circ} \mathrm{C}$, and $\mathrm{D}$ ) $500{ }^{\circ} \mathrm{C}$, and for the corresponding regenerated catalysts. 

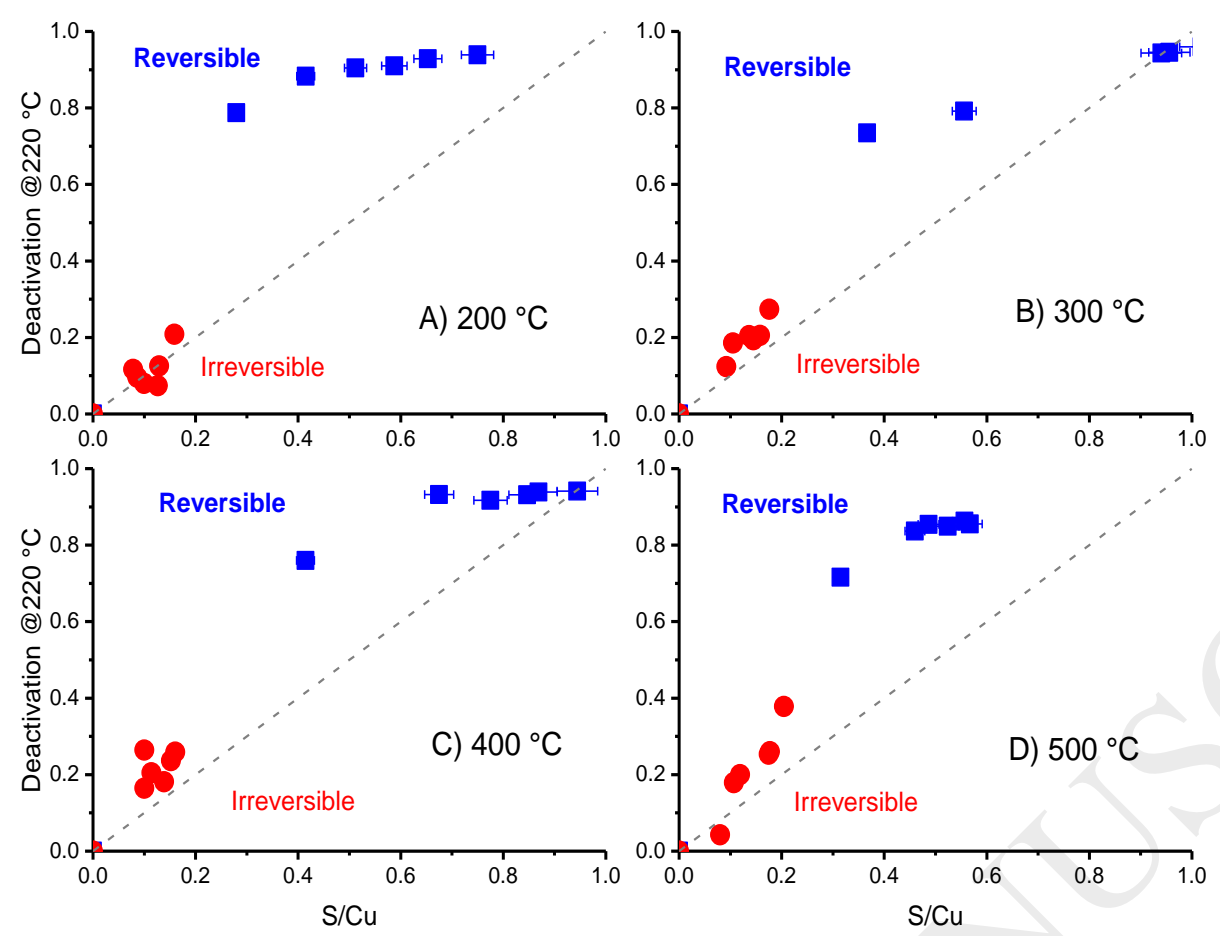

Figure 3 -Reversible (squares) and irreversible (circles) deactivation at $220^{\circ} \mathrm{C}$ plotted as functions of the $\mathrm{S} / \mathrm{Cu}$ ratios for the exposure temperatures A) $\left.\left.200^{\circ} \mathrm{C}, \mathrm{B}\right) 300^{\circ} \mathrm{C}, \mathrm{C}\right) 400{ }^{\circ} \mathrm{C}$, and D) $500{ }^{\circ} \mathrm{C}$.

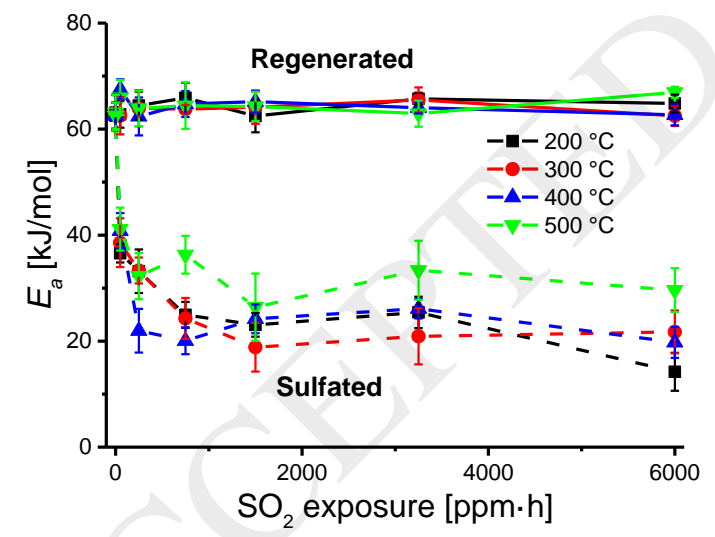

Figure 4-Activation energies in the $\mathrm{NH}_{3}-\mathrm{SCR}$ reaction for the $\mathrm{SO}_{2}$ exposed (dashed lines) and regenerated (solid lines) catalysts, plotted as functions of the total $\mathrm{SO}_{2}$ exposure. 


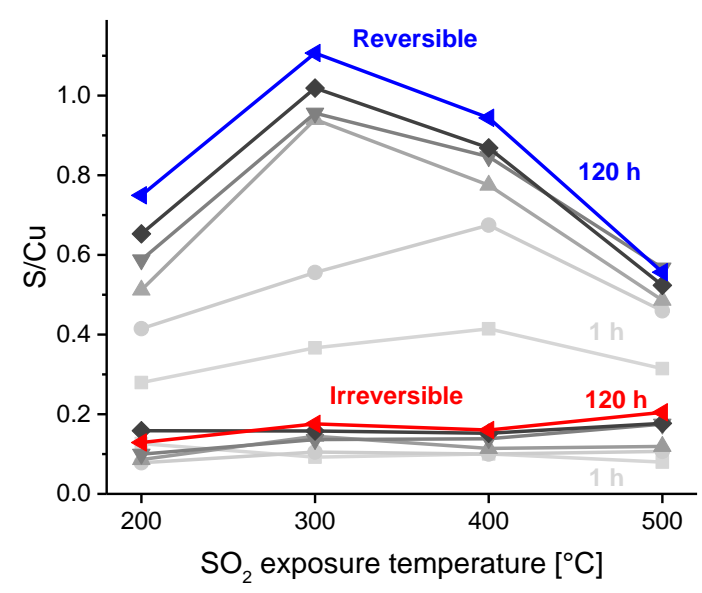

Figure 5 - Development of the reversible and irreversible $\mathrm{S} / \mathrm{Cu}$ ratios from $1 \mathrm{~h}$ to $120 \mathrm{~h}$ of $\mathrm{SO}_{2}$ exposure, plotted for each exposure temperature.

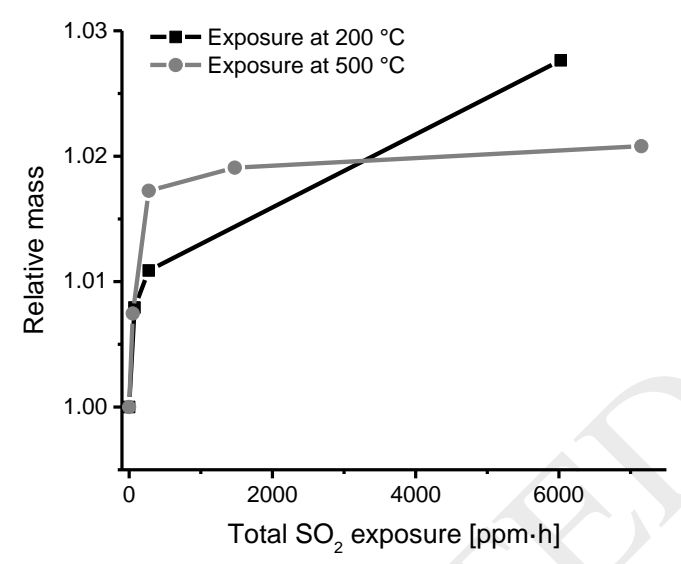

Figure 6-Relative masses of the catalysts exposed to $\mathrm{SO}_{2}$ at $200{ }^{\circ} \mathrm{C}$ (black) and $500{ }^{\circ} \mathrm{C}$ (grey) in the thermogravimetric setup, plotted as functions of the total $\mathrm{SO}_{2}$ exposure. 

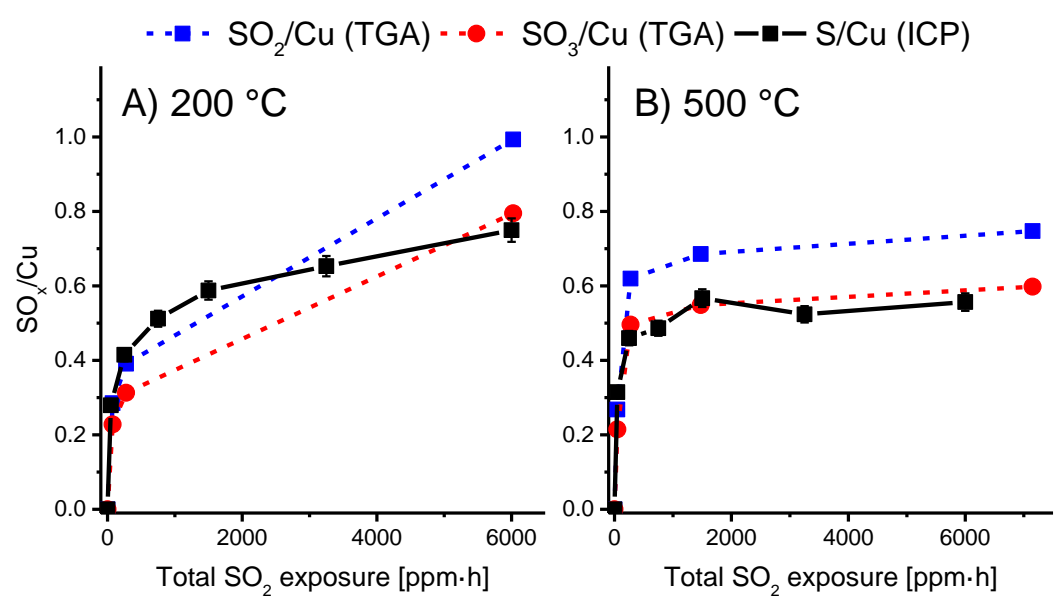

Figure $7-\mathrm{SO}_{x} / \mathrm{Cu}$ ratios plotted as functions of the total $\mathrm{SO}_{2}$ exposure for catalysts exposed to $\mathrm{SO}_{2}$ at $\left.\mathrm{A}\right) 200{ }^{\circ} \mathrm{C}$, and $\left.\mathrm{B}\right) 500{ }^{\circ} \mathrm{C}$. Black solid lines are $\mathrm{S} / \mathrm{Cu}$ ratios determined by ICP-OES on catalysts exposed to $\mathrm{SO}_{2}$ in the reactor setup. Dashed lines are $\mathrm{SO}_{2} / \mathrm{Cu}$ ratios (blue squares) and $\mathrm{SO}_{3} / \mathrm{Cu}$ ratios (red circles) based on the mass increase measured in the thermogravimetric setup. 